\title{
STUDI EKSPLORASI PENGELOLAAN DAN KEPUASAN DALAM PEMANFAATAN SARANA DAN PRASARANA WORKSHOP YANG TELAH MENERAPKAN SISTEM MANAJEMEN MUTU ISO 9001
}

\author{
Alfian S. Pratama1, Bambang Darmawan², Ibnu Mubarak ${ }^{3}$ \\ Universitas Pendidikan Indonesia \\ Jl. Dr. Setiabudi No. 229 Bandung 40154 \\ alfianotomotif03@gmail.com
}

\begin{abstract}
ABSTRAK
Tujuan penelitian ini untuk mengetahui pengelolaan dan kepuasan peserta didik dalam pemanfaatan sarana dan prasarana di workshop teknik sepeda motor. Metode penelitian yang digunakan deskriptif dengan pendekatan kuantitatif. Sampel pada penelitian ini adalah kepala bengkel dan peserta didik SMK X Bandung dengan subyek kepala bengkel sebanyak 1 orang dan peserta didik kelas XI sebanyak 42 peserta didik. Teknik pengumpulan data menggunakan mangket, observasi dan dokumentasi. Hasil penelitian menunjukkan bahwa pada area kerja mesin, chasis, kelistrikan otomotif untuk kontak listrikjumlahnya tidak sesuai dengan standar BSNP yang digunakan. Ruang penyimpanan dan instruktur untuk meja kerja, kursi kerja, lemari alat dan bahan, sarana training object sepeda motor, media engine stand, media kelistrikan, peralatan utama bengkel untuk dial test indicator, peralatan pendukung bengkel meja kerja dan trolly tidak sesuai dengan standar BSNP yang digunakan. Kesimpulan penelitian ini adalah pengelolaan sarana dan prasarana workshop sudah sangat baik dan peserta didik dalam pemanfaatan sarana dan prasarana sudah memuaskan, namun masih belum sesuai dengan standar BNSP.
\end{abstract}

Kata kunci: sarana dan prasarana, manajemen mutu ISO, teknik otomotif

\section{PENDAHULUAN}

Perkembangan ilmu pengetahuan dan teknologi (IPTEK) menuntut sekolah untuk dapat menyesuaikan dengan arus perubahan. Lulusan sekolah harus sesuai dengan tuntutan perkembangan zaman. Efektivitas kegiatan kependidikan sekolah dipengaruhi variabel yang menyangkut salah satu aspek yaitu sarana dan prasarana, yang perlu mendapatkan pembinaan dan pengembangan secara berkelanjutan. Sarana dan prasarana pendidikan dalam proses pembelajaran adalah salah satu faktor yang penting. Sarana dan prasarana pendidikan ini sebagai instrumental input dalam pendidikan memegang peranan penting dalam proses pembelajaran (Lunenburg, 2010). Sarana dan prasarana pendidikan mampu memperjelas kebutuhan peserta didik dalam pencapaian tujuan pendidikan.

Sarana pendidikan ini berkaitan erat dengan semua perangkat, peralatan, bahan dan perabot yang secara langsung digunakan dalam pelayanan pendidikan. Sedangkan prasarana pendidikan berkaitan dengan semua perangkat kelengkapan dasar yang secara tidak

\footnotetext{
${ }^{1}$ Mahasiswa Departemen Pendidikan Teknik Mesin FPTK UPI

2 Dosen Departemen Pendidikan Teknik Mesin FPTK UPI

3 Dosen Departemen Pendidikan Teknik Mesin FPTK UPI
} 
langsung menunjang pelaksanaan proses pembelajaran di sekolah seperti: ruang perpustakaan, ruang praktikum, kantor sekolah, usaha kesehatan sekolah (UKS), ruang osis, tempat parkir, ruang laboratorium, dan lain-lain. Sekolah Menengah Kejuruan tanpa sarana dan prasarna tidak akan berjalan dengan baik, secara umum kegiatan belajar mengajar di sekolah menengah kejuruan (SMK) meliputi teori dan praktik (Barnawi dan Arifin, 2012). Kegiatan belajar teori pada prinsipnya sama dengan sekolah umum. Sedangkan kegiatan belajar praktik merupakan kegiatan belajar yang seharusnya lebih banyak dibanding dengan kegiatan teori karena siswa dituntut untuk memiliki keahlian tertentu di bidang kejuruannya. Oleh karena itu, untuk menunjang kegiatan belajar praktik di SMK diperlukan sarana prasarana yang memadai seperti bengkel dan laboratorium. Tanpa tersedianya sarana dan prasarana tersebut, SMK akan menjadi teori saja. Terlihat jelas bahwa sarana dan prasarana untuk SMK itu sangat diperlukan demi menunjang kegiatan belajar mengajar dalam praktik pembelajaran.

Keberhasilan mutu pelayanan pembelajaran di sekolah didukung oleh pendayagunaan semua sarana dan prasarana pendidikan yang ada di sekolah secara efektif dan efisien. Sarana dan prasarana yang ada di sekolah tersebut perlu didayagunakan dan dikelola untuk meningkatkan mutu layanan pembelajaran. Pengelolaan itu dimaksudkan agar menggunakan sarana dan prasarana di sekolah bisa berjalan dengan efektif dan efisien (Lantip, 2010).

Sebuah lembaga pendidikan harus menyadari bahwa keberhasilan proses pembelajaran di sekolah sangat dipengaruhi tersedia tidaknya kelengkapan sarana prasarana pendidikan. Peningkatan pendidikan akan sulit dilaksanakan jika sarana yang ada kurang lengkap atau ada tetapi kurang terkelola. Seorang pendidik pun terkadang kurang mengoptimalkan sarana yang ada dalam proses pembelajaran, karena pemborosan waktu, tenaga, bahkan tidak sedikit juga kurang paham cara penggunaan sarana yang ada. Banyak sarana dan prasarana pendidikan yang dimiliki oleh sekolah diterima sebagai bantuan, baik dari pemerintah maupun swasta/masyarakat tidak optimal penggunaannya (Soekartawi, 2005). Bahkan tidak dapat lagi digunakan sesuai dengan fungsinya. Keadaan seperti itu disebabkan antara lain oleh kurangnya kepedulian terhadap sarana dan prasarana yang dimiliki serta tidak adanya pengelolaan yangmemadai.

Proses layanan pembelajaran yang bermutu ditentukan oleh berbagai unsur dinamis yang ada di sekolah dan lingkungannya sebagai kesatuan sistem. Mutu merupakan kondisi dinamis yang berhubungan dengan produk, jasa, manusia, proses, dan lingkungan yang memenuhi harapan. Konsep mutu pendidikan mempunyai makna sebagai suatu kadar proses dan hasil pendidikan secara keseluruhan yang ditetapkan sesuai dengan kriteria tertentu. 
SMK dalam hal ini berupaya untuk menaikkan derajat mutu pendidikan Indonesia. Hal ini membawa implikasi pada tingkat pengetahuan dan keterampilan yang perlu dimiliki oleh siswa SMK khususnya program keahlian teknik otomotif. Oleh karena itu, manajemen pendidikan di bidang keahlian terutama pada sekolah kejuruan sangat dibutuhkan (Asnawir dan Usman, 2002). Manajemen yang dibutuhkan yaitu suatu sistem manajemen mutu yang diakui dan berstandar baik secara nasional bahkan internasional. Salah satu sistem manajemen mutu yang telah berstandar internasional yaitu ISO 9001. Demi mewujudkan mutu yang lebih baik dalam suatu lembaga pendidikan, maka beberapa lembaga pendidikan yang ada di Indonesia telah memulai untuk menerapkan sistem manajemen mutu ISO 9001:2008.

Seluruh SMK Negeri di kota Bandung telah memiliki sertifikasi ISO 9001 dalam pengelolaan manajemen di sekolah. SMK X Bandung sendiri telah memperoleh sertifikat standar ISO, penggunaan sistem manajemen mutu ISO 9001 menjadi pilihan terbaik yang dilakukan untuk meningkatkan kualitas Sekolah Menengah Kejuruan (SMK) dengan baik. Penerapan sistem manajemen mutu terbaru ini diharapkan sebagai wujud realisasi produk yang dihasilkan dengan optimal. SMK X Bandung diharuskan menjalankan semua prosedur standar yang telah digariskan dalam persyaratan sistem manajemen mutu ISO 9001 yang tertuang dalam klausal implementasi secara berurutan dan berkelanjutan. Termasuk di dalamnya memenuhi persyaratan sarana dan prasarana serta menjalankan implementasi manajemen kualitas di dalam pengelolaannya (Mustari, 2014).

Namun demikian, masih adanya pengelolaan yang belum maksimal dilakukan oleh pihak sekolah. Temuan tersebut antara lain, luas workshop yang tidak sesuai dengan standar sarana dan prasarana, penataan workshop yang kurang teratur, alat peraga dan media pembelajaran yang sedikit, dan rasio jumlah alat praktikum dan peserta didik tidak sesuai dengan standar yang ditetapkan berdasarkan analisis ketidaktercapaian program kerja dokumen ISO Teknik dan Bisnis Sepeda Motor SMK X Bandung.

\section{METODE PENELITIAN}

Penelitian ini menggunakan metode deskristif pendekatan kuantitatif. Populasi dalam penelitian ini adalah kepala bengkel dan peserta didik kelas XI paket keahlian Teknik dan Bisnis Sepeda Motor di SMK X Bandung tahun ajaran 2017/2018 sebanyak 168 peserta didik. Data penelitian yang diperoleh dari sampel atau populasi penelitian yang dianalisis sesuai dengan metode statistik yang digunakan. Sampel diambil menggunakan teknik proporsional random sampling, yaitu sampel diambil 25\% dari populasi. Kepala bengkel 
yang berjumlah 1 orang, sedangkan peserta didik yang berjumlah 168 orang diambil sampel sebanyak 42 orang. Teknik pengumpulan data yang digunakan adalah angket atau kuisioner, dan dokumentasi. Angket yang digunakan jenis angket tertutup. Angket dibuat dengan pilihan jawaban yang disusun berdasarkan skala likert.

\section{HASIL PENELITIAN}

Hasil dari angket yang telah dijawab oleh responden, selanjutnya dilakukan pengolahan data dengan prosentase dari setiap indikator. Untuk mengetahui pengeloaan sarana dan prasarana yang terdiri dari perencanaan, pengadaan, pemanfaatan, pemeliharaan, dan pengawasan. Untuk kepuasan peserta didik dalam pemanfaatan alat dan bahan praktikum terdiri dari estetika, kinerja, fitur, kesesuaian, kemampuan pelayanan, daya tahan, dan kegunaan yang sesuai. Observasi dilakukan untuk mengetahui ketersediaan dan ketercukupan alat dalam melaksanakan praktikum.

Pengelolaan sarana dan prasarana yang dilihat pada tiap indikator yaitu perencanaan sebesar $68,6 \%$, pengadaan sebesar 74,3\%, pemanfaatan sebesar $93,3 \%$, pemeliharaan sebesar 93,3\%, dan pengawasan sebesar 90\%. Jumlah total prosentase pengelolaan sarana dan prasarana workshop adalah sebesar $82,6 \%$. Kepuasan peserta didik dalam pemanfaatan sarana dan prasarana yang dilihat pada tiap indikator yaitu estetika sebesar $82,2 \%$, kinerja sebesar $77,4 \%$, fitur sebesar $81,3 \%$, kesesuaian sebesar 74,8\%, kemampuan pelayanan sebesar $78,1 \%$, daya tahan sebesar $76,9 \%$, dan kegunaan yang sesuai sebesar $82,6 \%$. Jumlah total prosentase kepuasan peserta didik dalam pemanfaatan sarana dan prasarana workshop adalah sebesar $67,7 \%$.

\section{PEMBAHASAN}

Pengelolaan adalah penyelenggaraan atau pengurusan agar Sesuatu yang dikelola dapat berjalan dengan lancar dan efektif. Pengukuran dilakukan pada pengelolaan sarana dan prasarana workshop di paket keahlian Teknik dan Bisnis Sepeda Motor. Beberapa indikator yang termasuk ke dalam pengelolaan sarana dan prasarana antara lain: perencanaan, pengadaan, pemanfaatan, pemeliharaan dan pengawasan.

Semua anggota organisasi khususnya pemimpin memikirkan semua strategi untuk mencapai semua tujuan, baik cara keberhasilannya (Stoner, 2006). Kemungkinan dari keberhasilannya, siapa dan apa saja yang dilibatkannya dalamperencanaan ini. Hal-hal lain yang perlu diperhatikan sebelum pelaksanaan suatu rencana tersebut dilaksanakan. Pemimpin dalam hal ini adalah kepala bengkel paket keahlian Teknik dan Bisnis Sepeda 
Motor. Kepala bengkel melakukan perencanaan terkait sarana dan prasarana workshop.

Perencanaan adalah suatu proses memikirkan dan menetapkan kegiatan dan program yang akan dilakukan di masa yang akan datang untuk mencapai tujuan. Perencanaan perlengkapan sekolah adalah suatu proses memikirkan dan menetapkan program pengadaan fasilitas yang ada di sekolah. Sarana maupun prasarana pendidikan di masa yang akan datang sehingga tujuan yang ingin dicapai sekolah dapat terwujudkan (Soekartawi and Librero, 2002). Hasil penelitian pada indikator ini menunjukkan hasil prosentase sebesar $68,6 \%$. Hal ini menunjukkan bahwa kriteria dalam perencanaan termasuk kriteria baik. Secara garis besarnya bahwa, perencanaan sarana dan prasarana workshop Teknik dan Bisnis Sepeda Motor yang dilakukan oleh sekolah telah tercapai.

Para pemimpin mengkoordinasikan sumber daya lainnya yang dimiliki organisasi. Setiap sumber daya ditempatkan sesuai dengan fungsinya masing-masing agar tujuan yang direncanakan bisa dicapai dengan lebih mudah, efektif, bahkan mungkin efisien. Pemimpin dalam hal ini adalah kepala bengkel paket keahlian Teknik dan Bisnis Sepeda Motor. Kepala bengkel melakukan pengadaan terkait sarana dan prasarana workshop.

Pengadaan merupakan segala kegiatan untuk menyediakan semua keperluan barang/benda/jasa bagi keperluan pelaksanaan tugas. Pengadaan barang adalah semua kegiatan penyediaan perlengkapan untuk menunjang pelaksanaan tugas sekolah. Pengadaaan perlengkapan sekolah adalah segala kegiatan yang dilakukan guna menyediakan perlengkapan yang diperlukan oleh sekolah untuk menunjang kegiatan belajar mengajar agar dapat berjalan dengan efektif dan efisien (Saud, 2010). Hasil dari data pengolahan yang diambil dari responden, pada indikator ini menunjukkan hasil prosentase sebesar 74,3\%. Hal ini menunjukkan bahwa kriteria dalam pengadaan termasuk kriteria baik. Secara garis besarnya bahwa, pengadaan sarana dan prasarana workshop Teknik dan Bisnis Sepeda Motor yang dilakukan oleh sekolah telah tercapai.

Usaha atau tindakan yang dilakukan untu mencapai tujuan organisasi. Rencana yang telah dilakukan dan diorganisasikan untuk mencapai tujuan organisasi sudah mulai dilaksanakan atau dijalankan. Pemimpin dalam hal ini adalah kepala bengkel paket keahlian Teknik dan Bisnis Sepeda Motor. Kepala bengkel melakukan pemanfaatan terkait sarana dan prasarana workshop.

Pemanfaatan merupakan serangkaian kegiatan terencana dan sistematis yang dilakukan secara rutin maupun berkala. Pemeliharaan sarana adalah kegiatan untuk melaksanakan pengurusan dan pengaturan agar semua sarana dan prasarana pendidikan selalu dalam keadaan baik dan siap utnuk digunakan secara berdaya guna dan berhasil guna dalam mencapai 
tujuan pendidikan. Hasil dari data pengolahan yang diambil dari responden, pada indikator ini menunjukan hasil prosentase sebesar 93,3\%. Hal ini menunjukkan bahwa kriteria dalam pemanfaatan termasuk kriteria sangat baik. Secara garis besarnya bahwa, Pemanfaatan sarana dan prasarana workshop Teknik dan Bisnis Sepeda Motor yang dilakukan oleh sekolah telah tercapai.

Usaha yang dilakukan para pemimpin untuk mengontrol pekerjaan dapat berjalan sesuai dengan visi, misi, aturan. Baik itu pengawasan, inspeksi sampai audit. Pemimpin dalam hal ini adalah kepala bengkel paket keahlian Teknik dan Bisnis Sepeda Motor. Kepala bengkel melakukan pemeliharaan terkait sarana dan prasarana workshop.

Pemeliharaan adalah suatu kegiatan pemeliharaan yang terus menerus untuk mengusahakan agar setiap jenis barang dapat ditetapkan berada dalam keadaan baik atau siap pakai. Pemeliharaan dilakukan agar sarana dan prasarana tidak cepat rusak dan selalu dalam keadaan siap pakai dalam proses/kegiatan belajar mengajar. Pemeliharaan dilakukan agar barang-barng yang disimpan atau dipakai selalu dalam keadaan baik dan dapat siap pakai (Bafadal, 2004). Hasil dari data pengolahan yang diambil dari responden, pada indikator ini menunjukkan hasil prosentase sebesar 93,3\%. Hal ini menunjukkan bahwa kriteria dalam pemeliharaan termasuk kriteria sangat baik. Secara garis besarnya bahwa, pemeliharaan sarana dan prasarana workshop Teknik dan Bisnis Sepeda Motor yang dilakukan oleh sekolah telah tercapai.

Pengelolaan sarana dan prasarana pendidikan tidak dapat lepas dari pengawasan. Pemberian arahan penggunaan sarana prasarana pendidikan oleh guru serta proses pelaksanaan pengawasan sarana pendidikan yang digunakan oleh peserta didik (Owoeye, and Yara, 2011). Hasil dari data pengolahan yang diambil dari responden, pada indikator ini menunjukkan hasil prosentase sebesar 90\%. Hal ini menunjukkan bahwa krirteria dalam pengawasan termasuk kriteria sangat baik. Secara garis besarnya bahwa, pengawasan sarana dan prasarana workshop Teknik dan Bisnis Sepeda Motor yang dilakukan oleh sekolah tercapai.

Pengukuran kepuasan peserta didik dalam pemanfaatan sarana dan prasarana workshop ini dilakukan pada peserta didik kelas XI Teknik dan Bisnis Sepeda Motor saat kegiatan praktikum di workshop pada mata pelajaran pemeliharaan mesin sepeda motor, pemeliharaan kelistrikan sepeda motor, dan pemeliharaan sasis sepeda motor yang telah dilakukan selama semester ganjil. Jenis peralatan yang digunakan dalam praktikum adalah hand tools, special service tools, dan alat ukur. Hand tools yang digunakan terdiri dari: kunci pas, kunci ring, kunci sok, tang, palu, adjustible wrench, rachet, extension bar, feeler gauge dan mata sok. Special service tools yang digunakan terdiri dari: multitester dan impact driver. Alat ukur 
yang digunakan adalah vernier caliper (jangka sorong). Beberapa indikator yang termasuk ke dalam kepuasan peserta didik dalam pemanfaatan sarana dan prasarana antara lain: estetika, kinerja, fitur, kesesuaian, kemampuan pelayanan, daya tahan dan kegunaan yang sesuai. Setelah dilakukan pengolahan data berikut presentase tiap indikatornya.

Kepuasan siswa dipengaruhi oleh faktor ekstrinsik. Faktor ekstrinsik itu sendiri dari luar diri siswa, antara lain; kualitas mengajar guru, budaya sekolah, sarana dan prasarana di sekolah serta iklim sekolah (Sopiatin, 2010). Penelitian ini untuk mengukur tingkat kepuasan siswa terhadap pemanfaatan sarana dan prasarana workshop teknik sepeda motor yaitu dengan menggunakan dimensi kualitas produk berupa barang. Kualitas produk baik berupa barang maupun jasa sangat berkontribusi besar pada kepuasan seseorang. Untuk menentukan dimensi kualitas suatu barang salah satunya adalah estetika.

Estetika merupakan karakteristik yang bersifat subyektif mengenai nilai-nilai yang berkaitan dengan pertimbangan pribadi dan refleksi dari preferensi individual mengenai tampilan fisik sarana dan prasarana. Hasil dari data pengolahan yang diambil dari responden, pada indikator ini menunjukkan hasil prosentase sebesar $82,2 \%$. Hal ini menunjukkan bahwa kriteria dalam estetika termasuk kriteria sangat memuaskan. Secara garis besarnya bahwa, estetika dalam kepuasan pemanfaatan sarana dan prasarana workshop Teknik dan Bisnis Sepeda Motor yang dirasakan oleh peserta didik tercapai.

Kinerja merupakan aspek fungsional suatu barang dan merupakan karakteristik utama yang dipertimbangkan peserta didik dalam pemakaian barang sarana dan prasarana Hasil dari data pengolahan yang diambil dari responden, pada indikator ini menunjukkan hasil prosentase sebesar 77,4\%. Hal ini menunjukan bahwa kriteria dalam kinerja termasuk kriteria memuaskan. Secara garis besarnya bahwa, Kinerja dalam kepuasan pemanfaatan sarana dan prasarana workshop Teknik dan Bisnis Sepeda Motor yang dirasakan oleh peserta didik tercapai.

Fitur merupakan aspek fungsional suatu kegunaan fungsi dasar dan karakteristik kelengkapan sesuai tujuan. Hasil dari data pengolahan yang diambil dari responden, pada indikator ini menunjukkan hasil prosentase sebesar $81,3 \%$. Hal ini menunjukan bahwa kriteria dalamfitur termasuk kriteria sangat memuaskan. Secara garis besarnya bahwa, Fitur dalam kepuasan pemanfaatan sarana dan prasarana workshop Teknik dan Bisnis Sepeda Motor yang dirasakan oleh peserta didik tercapai.

Kepuasan siswa dipengaruhi oleh faktor ekstrinsik. Faktor ekstrinsik itu sendiri dari luar diri siswa, antara lain; kualiatas mengajar guru, budaya sekolah, sarana dan prasarana di sekolah serta iklim sekolah. Penelitian ini untuk mengukur tingkat kepuasan siswa 
terhadap pemanfaatan sarana dan prasarana workshop teknik sepeda motor yaitu dengan menggunakan dimensi kualitas produk berupa barang, karena kualitas produk baik berupa barang maupun jasa sangat berkontribusi besar pada kepuasan seseorang. Untuk menentukan dimensi kualitas suatu barang salah satunya adalah kesesuaian.

Kesesuian merupakan rasio jumlah kebutuhan sarana dan prasarana dengan jumlah peserta didik dalam melakukan praktikum. Hasil dari data pengolahan yang diambil dari responden, pada indikator ini menunjukkan hasil prosentase sebesar 74,8\%. Hal ini menunjukkan bahwa kriteria dalam kesesuaian termasuk kriteria memuaskan. Secara garis besarnya bahwa, kesesuaian dalam kepuasan pemanfaatan sarana dan prasarana workshop Teknik dan Bisnis Sepeda Motor yang dirasakan oleh peserta didik tercapai.

Kemampuan pelayanan merupakan karakteristik yang berkaitan dengan kecepatan, kompetensi, kemudahan, dan akurasi dalam memberikan layanan untuk peminjaman alat dan bahan praktikum. Hasil dari data pengolahan yang diambil dari responden, pada indikator ini menunjukkan hasil prosentase sebesar 78,1\%. Hal ini menunjukan bahwa kriteria dalam kemampuan pelayanan termasuk kriteria memuaskan. Secara garis besarnya bahwa, Kemampuan pelayanan dalam kepuasan pemanfaatan sarana dan prasarana workshop Teknik dan Bisnis Sepeda Motor yang dirasakan oleh peserta didik tercapai.

Daya tahan merupakan kekuatan pemakaian alat dan bahan yang digunakan oleh peserta didik saat melaksanakan praktikum pembelajaran. Hasil dari data pengolahan yang diambil dari responden, pada indikator ini menunjukan hasil prosentase sebesar 76,9\%. Hal ini menunjukkan bahwa kriteria dalam daya tahan termasuk kriteria memuaskan. Secara garis besarnya bahwa, daya tahan dalam kepuasan pemanfaatan sarana dan prasarana workshop Teknik dan Bisnis Sepeda Motor yang dirasakan oleh peserta didik tercapai.

Kepuasan siswa dipengaruhi oleh faktor ekstrinsik. Faktor ekstrinsik itu sendiri dari luar diri siswa, antara lain; kualiatas mengajar guru, budaya sekolah, sarana dan prasarana di sekolah serta iklim sekolah. Penelitian ini untuk mengukur tingkat kepuasan siswa terhadap pemanfaatan sarana dan prasarana workshop teknik sepeda motor (Minarti, 2011). Pengukuran menggunakan dimensi kualitas produk berupa barang, karena kualitas produk baik berupa barang maupun jasa sangat berkontribusi besar pada kepuasan seseorang. Untuk menentukan dimensi kualitas suatu barang salah satunya adalah kegunaan yang sesuai.

Kegunaan yang sesuai merupakan perasaan peserta didik mengenai ketepatan penggunaan sarana dan prasarana. Hasil dari data pengolahan yang diambil dari responden, pada indikator ini menunjukkan hasil prosentase sebesar $82,6 \%$. Hal ini menunjukan bahwa kriteria dalam kegunaan yang sesuai termasuk kriteria sangat memuaskan. Secara garis 
besarnya bahwa, kegunaan yang sesuai dalam kepuasan pemanfaatan sarana dan prasarana workshop Teknik dan Bisnis Sepeda Motor yang dirasakan oleh peserta didik tercapai.

Hasil eksplorasi yang telah dilakukan pada area kerja mesin otomotif untuk kontak listrik jumlahnya tidak sesuai dengan standar BSNP yang digunakan. Area kerja kelistrikan otomotif untuk meja kerja, kursi kerja, lemari simpan alat dan bahan, dan kontak listrik tidak sesuai dengan standar BSNP yang digunakan. Area kerja chasis otomotif untuk kontak listrik jumlahnya tidak sesuai dengan standar BSNP yang digunakan. Ruang penyimpanan dan instruktur untuk meja kerja, kursi kerja, dan lemari simpan alat dan bahan tidak sesuai dengan standar BSNP yang digunakan. Sarana training object sepeda motor, media engine stand, dan media kelistrikan tidak sesuai dengan standar BSNP yang digunakan. Peralatan utama bengkel Teknik dan Bisnis Sepeda Motor untuk dial test indicator tidak sesuai dengan standar BSNP yang digunakan. Peralatan pendukung bengkel Teknik dan Bisnis Sepeda Motor untuk meja kerja dan trolly tidak sesuai dengan standar BSNP yang digunakan.

\section{KESIMPULAN}

Kesimpulan penelitian ini sebagai berikut: pengelolaan sarana dan prasarana di workshop Teknik Sepeda Motor termasuk sangat baik dan kepuasan peserta didik dalam pemanfaatan sarana dan prasarana di workshop termasuk sudah memuaskan.

\section{REFERENSI}

Asnawir dan Usman, M. B. (2002). Media Pembelajaran. Jakarta: Ciputat Pers.

Bafadal, I. (2004). Manajemen Perlengkapan Sekolah: Teori dan Aplikasinya. Jakarta: PT. Bumi Aksara.

Barnawi dan Arifin, M. (2012). Manajemen Sarana dan Prasarana Sekolah. Yogyakarta: Ar-Ruzz Media.

Lantip, D. P. (2010). Financial Resources Sebagai Faktor Penentu dalam Implementasi Kebijakan Pendidikan. Jurnal Internasional Manajemen Pendidikan. 4(2).

Lunenburg, F. C. (2010). School Facilities Management. National Forum of Educational Administration \& Supervision Journal. 27 (4).

Minarti, S. (2011). Manajemen sekolah: Mengelola Lembaga Pendidikan Secara Mandiri. Yogyakarta: Ar-Ruzz Media.

Mustari, M. (2014). Manajemen Pendidikan. Jakarta: Rajawali Pers 
Owoeye, J. S. and Yara, P. O. (2011). School Facilities and Academic Achievement of Secondary School Agricultural Science in Ekiti State, Nigeria. Asian Sosial Science, 7(7).

Saud, U. S. (2010). Inovasi Pendidikan. Bandung: Alfabeta.

Soekartawi, A. H., and Librero, F. (2002). Greater Learning Opportunities Throught Distance Education: Experiences in Indonesia and the Philippines. Southeast Journal of Education.

Soekartawi, A. H. (2005). Monitoring dan Evaluasi Proyek Pendidikan. Jakarta: PT Rajawali Press.

Sopiatin, P. (2010). Manajemen Belajar Berbasis Kepuasan Siswa. Jakarta: Ghalia Indonesia.

Stoner, A. F. J. (2006). Manajemen Jilid I. Jakarta: Erlangga. 